\title{
Leunca (Solanum nigrum L.) Herbs Ethanolic Extract Increase Cytotoxic Activity of Cisplatin on Hela Cervical Cancer Cells
}

\author{
Raditya Prima Istiaji ${ }^{1}$, Maya Fitria, Larasati, Fortunella Tjondro, \\ Astrid Ayu Maruti, Erna Prawita Setyowati, Edy Meiyanto* \\ ${ }^{1}$ Cancer Chemoprevention Research Center, Faculty of Pharmacy, \\ Universitas Gadjah Mada, Yogyakarta \\ *Corresponding author email: meiyan_e @ugm.ac.id, \\ Cancer Chemoprevention Research Center, Faculty of Pharmacy UGM, Yogyakarta,
}

\begin{abstract}
Cervical cancer is one of leading causes of cancer death in women in the developing countries. The use of cisplatin as chemotherapy agent in cervical cancer is known to cause side effects and also resistance for long-term uses. One of the strategies to prevent cervical cancer based on combination agents is being developed. Leunca (Solanum nigrum L.) has been revealed to inhibit growth of human cancer cells. Therefore, it can be used in combination with cisplatin to reduce those side effects and prevent the occurrence of cell resistance. Ethanolic extract of Leunca Herb (ELH) and cisplatin were tested their cytotoxic effect on HeLa cervical cancer cell by using MTT assay to determine IC50 value. The combinationss of cisplatin-ELH were tested to determine the combination index $(\mathrm{Cl}$ value). The IC50 of ELH and cisplatin on HeLa cells were $227 \mu \mathrm{g} / \mathrm{mL}$ and $17 \mu \mathrm{M}$. rRespectively. Tthe study of combination resulted that almost all the index combinations were $<0,9$ showed the effect of synergism combination. The Ooptimum concentration of combination was I/8 IC50 cisplatin-I/8 IC50 ELH. The results indicated that ELH had a potency to be combination agent to enhance the activity of cisplatin on HeLa cervical cancer cells. Therefore, further study on its molecular mechanism needs to be explored.
\end{abstract}

Key words: Leunca (Solanum nigrum L.), cisplatin, cytotoxic, combination agent, HeLa cells.

\section{INTRODUCTION}

Cervical cancer remains to be the one of the greatest killers of women in the worldwide. Cisplatin as the chemotherapy in cervical cancer gave side effects like nephrotoxicity, neurotoxicity, ototoxicity, nausea, vomiting and resistant (Cepeda et al., 2007; Fuertes et al., 2003). The use of herbal medicines in combination with chemotherapy is one of the better ways in the treatment of advanced cancer cases because it can improve efficacy and reduce toxicity (Liu et al., 2006) Therefore, the research about alternative cancer therapy using herbal extract as combination with chemotherapy is important to be developed.

Leunca (Solanum nigrum L.) is the plant that has anticancer activity. The previous in vitro studies showed that $\beta$-2-solamargine on Leunca had cytotoxic effect on tumor cell lines HT-29 (colon), HCT-15 (colon), LNCaP (prostate), PC-3 (prostate), T47D (breast), and MDA-MB-231 (breast) (Hu et al., 1999). The other studies, proved that solamargine could modulate the expressions of TNFRs and Bcl-2 on H441, H520, H661 and H69 human lung cancer cells (Liu et al., 2004). Then solanine, a steroid alkaloid isolated from Leunca was known inducing apoptosis in HepG(2) cells seems to be mediated by the inhibition of Bcl-2 expression (Ji et al., 2008).

The researches above revealed that Leunca had a potency to be anti-cancer agent. This study aims to explore the cytotoxic effect of Leunca and its influence in combination with Cisplatin on HeLa cervical cancer cells.

*Corresponding author email : meiyan_e@ugm.ac.id, http://ccrc.farmasi.ugm.ac.id 


\section{METHODS}

\section{Ethanolic Extract of Leunca Herb}

(ELH). Leunca herb dried powder was harvested and determinated by Balai Besar Penelitian dan Pengembangan Tanaman Obat dan Obat Tradisional (B2P2TOOT), Tawangmangu, Central of Java. Then the herbs were extracted with maceration method by using ethanol $70 \%(1: 10)$.

Cell culture. HeLa cell line was obtained from Prof. Tatsuo Takeya (Nara Institute of Science and Technology, Japan) and grown in Dulbecco's modified Eagle's medium (DMEM; Gibco) supplemented with $10 \%$ fetal bovine serum (FBS; Gibco) and 1\% \% $/ v$ Penisilin-Streptomisin (Gibco) at temperature $37^{\circ} \mathrm{C}$ and with a flow of $5 \% \mathrm{CO}_{2}$.

\section{Cytotoxic assay with MTT} method. HeLa was planted in 96-well plates with $5 \times 10^{3}$ cells/well and divided into control and treatment group. Final concentrations of ELH were $1,5,10,25,50,100$ and $250 \mu \mathrm{g} / \mathrm{mL} .10 \mathrm{mg}$ of ELH was dissolved in dimethyl sulfoxide (DMSO) then diluted in culture medium until final concentrations. Concentrations of Cisplatin were 1 , $2,5,10,20,30$ and $50 \mu \mathrm{M}$. After $24 \mathrm{~h}$ incubation, culture medium was removed and cells were washed using PBS (Sigma). $5 \mathrm{mg} / \mathrm{mL}$ of MTT on PBS (Sigma) was diluted by DMEM (1:10) and $100 \mu \mathrm{l}$ of it was added into each well. After incubate for 3 hours the reaction was stopped by Sodium Dodecyl Sulfate (SDS) $10 \%$ in HCL 0,1
N. After that, the plate was incubated for one night in room condition at dark place. To make sure the formazan dissolve, the plate was shaked for 10 minutes and measured the absorbance using ELISA reader at wave length of $595 \mathrm{~nm}$. The concentration applied on combination chemotherapy of ELH was referred to $\mathrm{IC}_{50}$ value of each compound. The final combination concentrations of ELH were 30, 60, 90 and 120 $\mu \mathrm{g} / \mathrm{mL}$, and for cisplatin concentration were $2,4,6$ and $8 \mu \mathrm{M}$.

Statatistical analysis and data interpretation. Absorbances measured from cytotoxic assay were analyzed by Excell MS Office and semi-log analysis (SPSS 11.5) to obtain $\mathrm{IC}_{50}$ value (Doyle and Griffiths, 2000). The Combination Index/CI (table I) was calculated based on equation below :

$$
C \mathrm{I}=\frac{\mathrm{D} 1}{\mathrm{Dx} 1}+\frac{\mathrm{D} 2}{\mathrm{Dx} 2}
$$

Table I. Interpretation of $\mathrm{Cl}$ Values

\begin{tabular}{cc}
\hline CI Value & Interpretation \\
\hline$<0,1$ & very strong synergistic effect \\
$0,1-0,3$ & strong synergistic effect \\
$0,3-0,7$ & synergistic effect \\
$0,7-0,9$ & moderate synergistic effect \\
$0,9-1,1$ & nearly additive effect \\
$1,1-1,45$ & moderate antagonist effect \\
$1,45-3,3$ & antagonist effect \\
$>3,3$ & very strong antagoni effect st \\
\hline
\end{tabular}




\section{RESULTS}

Cytotoxic effect of Leunca Herb etanolic extract on HeLa cells. The result showed that ELH has cytotoxic effect on HeLa cells with IC50 value ofwas $227 \mu \mathrm{g} / \mathrm{ml}$ (Figure 1A) while for cisplatin has the IC50 value was of $17 \mu \mathrm{M}$ (Figure 1B).This IC50 value showed that ELH has the potency to inhibit HeLa cells growth. Therefore, Leunca could be used as a combination agent for cervical cancer treatment.

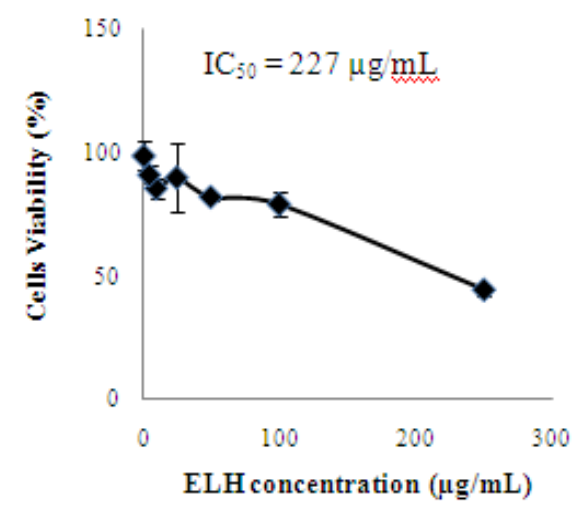

(A)

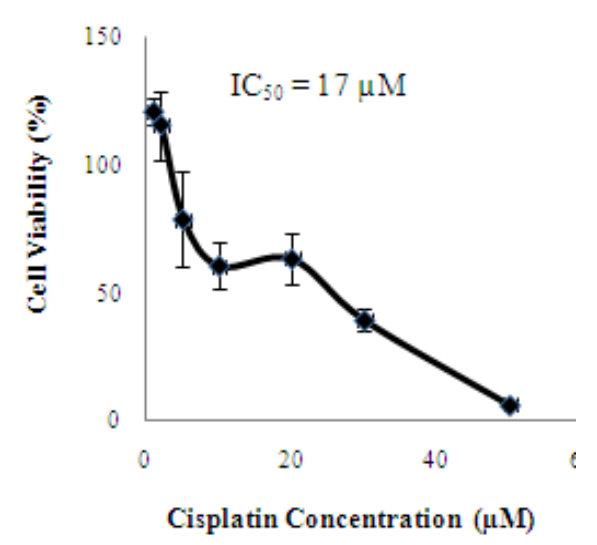

(B)

Figure I. The cytotoxic effect of HeLa cells. Treatment of ELH (A) and cisplatin (B) The data were obtained by MTT assay with the incubation of cells for $24 \mathrm{~h}$ at temperature of $37^{\circ} \mathrm{C}$ and flow of $5 \% \mathrm{CO}_{2}$. Each dot represent the means \pm SD from 3 replication.

\section{The Combination effect of Leunca Herb etanolic extract and cisplatin on HeLa cells.}

Despite its success, cisplatin has several disadvantages, like side effects and also the occurrence of resistance. Therefore, the combination of chemotherapeutic agent and herb extract expected to increase the chemotherapeutic agent activity and also inhibit the occurrence of resistance.

The parameter of combination effect was CI value, which used to assess the degree of combination effect in each concentration of combination. The combination of ELH-cisplatin gave synergistic effect because almost all the CI value were under 0,9 (Fig 2\&3, table 2). The combination of ELH-cisplatin that gave the biggest synergistic effect consisted of $30 \mu \mathrm{g} / \mathrm{mL}$ ELH - 2 $\mu \mathrm{M}$ cisplatin and $90 \mu \mathrm{g} / \mathrm{mL}$ ELH - $2 \mu \mathrm{M}$ cisplatin. This combination gave CI value of 0,58 . The viability data showed that the combination of ELH-cisplatin $(120 \mu \mathrm{g} / \mathrm{ml}-8 \mu \mathrm{M})$ inhibited the growth of HeLa cells until $46 \%$. This was higher than result given by single dose of each agent on the same concentration. 


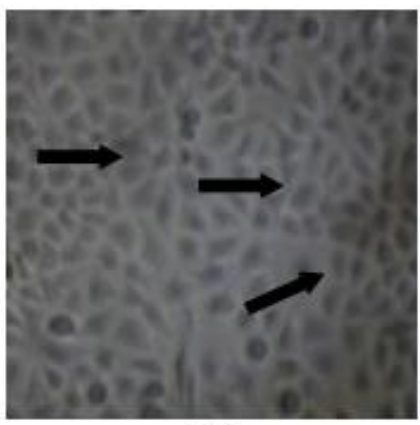

(A)

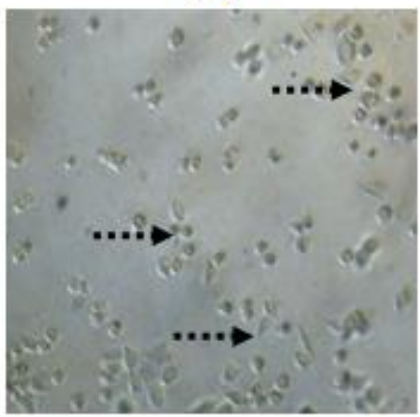

(C)



(B)

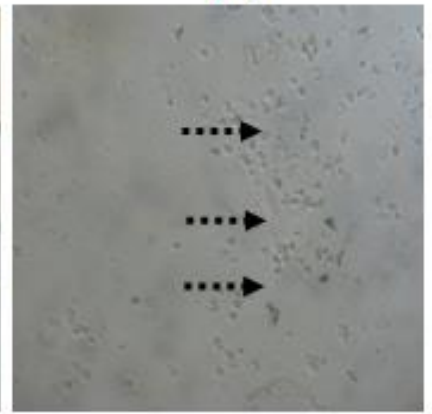

(D)

Figure 2. Combination effect of ELH-cisplatin on HeLa cells morphology. The picture was obtained by MTT assay with the incubation of cells for $24 \mathrm{~h}$ at temperature of $37^{\circ} \mathrm{C}$ and a flow of $5 \% \mathrm{CO}_{2}$. (A) cell control ; (B) ELH $250 \mu \mathrm{g} / \mathrm{mL}$; (C) ciplatin $8 \mu \mathrm{M}$; and (D) $120 \mu \mathrm{g} / \mathrm{mL}$ ELH- $2 \mu \mathrm{M}$ ciplatin. Normal HeLa cells $(\longrightarrow)$ and morphological changes of cells ( ...... )

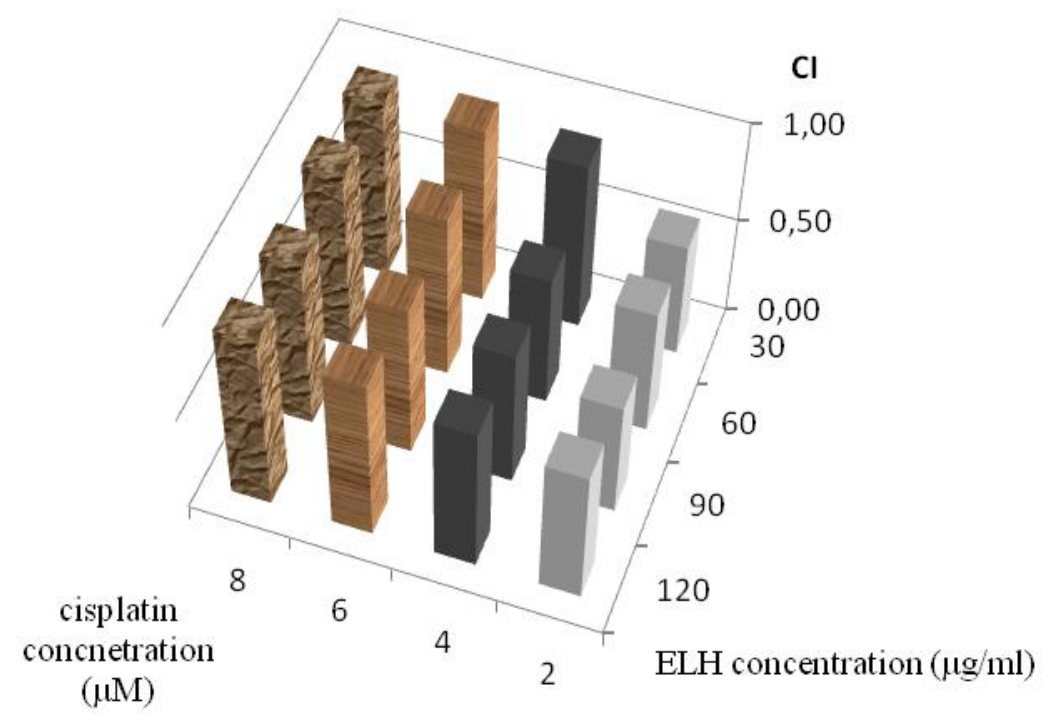

Figure 3. The $\mathrm{Cl}$ values of ELH-cisplatin combination on HeLa cells. The data were obtained by MTT assay with the incubation of cells for $24 \mathrm{~h}$ at temperature of $37^{\circ} \mathrm{C}$ and with a flow of $5 \% \mathrm{CO}_{2}$. 
Table II. Cl values of ELH-cisplatin combination. The bolds indicate $\mathrm{Cl}$ value $<0,9$ that have synergistic effect. The data was obtained by MTT assay.

\begin{tabular}{ccccc}
\hline \multirow{2}{*}{ Cisplatin $(\mu \mathrm{M})$} & \multicolumn{4}{c}{ Leunca Herb Extract $(\mu \mathrm{g} / \mathrm{mL})$} \\
\cline { 2 - 5 } & 30 & 60 & 90 & 120 \\
\hline 2 & 0,58 & 0,64 & 0,58 & 0,68 \\
4 & 0,86 & 0,67 & 0,70 & 0,74 \\
6 & 0,90 & 0,84 & 0,78 & 0,82 \\
8 & 0,91 & 0,92 & 0,86 & 0,89 \\
\hline
\end{tabular}

\section{DISCUSSION}

This study showed that ELH has cytotoxic activity and a synergistic effect in low concentration combination with cisplatin against HeLa cervical cancer cells. The mechanism of cancer cell growth inhibition occurs through many pathways such as apoptosis. Apoptosis is the process of programmed cell suicide in the normal condition, it's done to repair the broken tissues (Hanahan et al., 2000). Apoptosis occurs by the down-regulation of anti-apoptotic proteins such as Bcl-2. Based on the previous studies, Leunca contains Solanine and $\beta$-Solamargine that able to decrease the expression of protein Bcl-2 (Liu et al., 2004; Ji et al., 2008). Expression of Bcl-2 protein as an antiapoptosis protein can prevent cell death via apoptosis. Therefore its decreased expression could induce the cancer cells death (Pandanilam, 2003). In addition, Solamargine or Solanine could influence the upstream of the Bcl-2, then inhibits the transcription of $\mathrm{Bcl}-2$ protein. Finally, apoptosis can occur. Our study proved that ELH increased the cytotoxic activity of cisplatin on HeLa cervical cancer cells. Therefore, study about molecular mechanism of active compound found in Leunca Herb ethanolic extract that induce the cisplatin cytotoxic activity needs to be explored.

\section{CONCLUSION}

The conclusion of this study showed that combination between ELH and cisplatin gave synergistic effect on HeLa and induced the cytotoxic activity of cisplatin on HeLa cervical cancer cell.

\section{REFERENCES}

Cepeda, V., Miguel, A.F., Josefina, C., Carlos Alonso, Celia, Q. and Jose, M.P., 2007, Biochemical Mechanisms of Cisplatin Cytotoxicity, Anti-Cancer Agents in Medicinal Chemistry, 7(3), 3-18.

Doyle, A. and Griffiths, J.B., 2000, Cell and Tissue Culture for Medical Research, John Willey and Sons Ltd., New York.

Fuertes, M.A., Alonso, C. and Perez J.M., 2003, Biochemical modulation of Cisplatin mechanisms of action: enhancement of antitumor activity and circumvention of drug resistance, Chem Rev., 103, 645-62.

Hanahan, D. and Weinberg, R.A., 2000, The Hallmarks of Cancer, Cell, I 00, 57-70.

Hu, K., Kobayashi, H., Dong, A., Jing, Y., Iwasaki, S. and Yao, X., 1999, Antineoplastic agents. III: Steroidal glycosides from Solanum nigrum, Planta Med., 65(I), 35-8.

Ji, Y.B., Gao, S.Y., Ji, C.F. and Zou, X., 2008, Induction of apoptosis in HepG2 cells by solanine and $\mathrm{Bcl}-2$ protein, J Ethnopharmacol, I I 5(2), 194-202.

Liu, L.F., Liang, C.H., Shiu, L.Y., Lin, W.L., Lin, C.C. and Kuo, K.W., 2004, Action of Solamargine on Human Lung Cancer Cells-Enhancement of The Susceptibility of Cancer Cells to TNFs, FEBS Lett. 577(I-2), 67-74.

Liu Yi, Rui Wang, Gen-Quan Qiu, Ke-Jun Nan, and Xi-Cai Sun, 2006, Inhibitory effect of Fuzheng Yiliuyin in Combination with Chemotherapeutics on Human Gastric Carcinoma Cell Strain, World J Gastroenterol, I 2(25), 407|-4073. 
Padanilam, B.J., 2003, Cell Death Induced by Acute Renal Injury: A Perspective on the Contributions of Apoptosis and Necrosis, Am J Physiol Renal Physiol., 284, F608F627.
Reynolds and Maurer, 2005, Evaluating Response to Antineoplastic Drug Combination in Tissue Culture Models in Methods in Molecular Medicine, vol. II0, Humana Press inc., Totowa, NJ. 